\title{
Being Ralph Ellison: Remaking the Black Public Intellectual in the Age of Civil Rights
}

\section{Sterling Lecater Bland Jr.}

Most of the social realists of the period were concerned less with tragedy than with injustice. I wasn't, and am not, primarily concerned with injustice, but with art.--Ralph Ellison, "The Art of Fiction: An Interview"

Interviewer: How do you feel about the criticism you sometimes get from black students who feel you haven't been militant enough?

Ellison: I say, "You'd be your kind of militant and I'll be my kind of militant."-Interview with Ralph Ellison, Washington Post, August 1973

Soon after he published Invisible Man in April 1952, Ralph Ellison was quickly recognized as being the most prominent African American writer of his generation. Or, as Lawrence Jackson pointedly notes, "Ellison had moved from being an embattled social critic, a position he had occupied during most of the years he wrote Invisible Man, to being a symbol of America's willingness to accept talented blacks." The publication of Invisible Man, coupled with the National Book Award he received a year after its publication, heralded the arrival of a new, formidable African American voice on the mainstream literary stage. Ellison also became widely recognized as a public intellectual who came to rep- 
resent, to many, a writer whose ideas affirmed the possibilities of black American intellectualism. Ellison himself seemed to feel the same sense of possibility. The acceptance speech he gave after receiving the National Book Award spoke as directly to his elevated position as a novelist as it did to his desire to define and occupy his newly acquired public role and to shape his audience's thoughts about the ways he believed his work should be understood. Although Richard Wright was an early mentor of Ellison and supporter of the work he encouraged Ellison to do, Ellison quickly defined for himself a body of ideas and a foundation of American philosophical and political thought on which his literary and intellectual aspirations were self-consciously built. His political foundation was embodied by the ideas of Thomas Jefferson, Abraham Lincoln, and Ralph Waldo Emerson. His thoughts about literature were based in the literary production characterized by the writing of Mark Twain, John Dos Passos, Theodore Dreiser, T. S. Eliot, Ernest Hemingway, and William Faulkner. It is worth emphasizing that Ellison's literary apprenticeship was shaped by his association with a group of literary, intellectual, and political radicals who dismissed many of the New Negro movement's Africanist identifications in favor of Marxist readings of black proletarian experience in America that firmly radicalized the political solution to the "race problem."

My interest in this article is the period between the publication of Invisible Man and the early 1970s (roughly the period defined by the civil rights movement), when Ellison crafted his strategy for how he would define and occupy the public role in which he found himself and his work suddenly placed. As a public figure, Ellison engaged in a variety of broad cultural debates and conversations. While those ideas circulated in ways that Ellison certainly could not have controlled, my point here is that this was also the period when Ellison began a consciously revisionist process that deflected attention to his work away from its leftist origins and toward something that was decidedly more rooted in a language of aesthetics, of modernist impulse, and, most universally, of what he referred to in various ways as democratic possibility. When Ellison first began to control the narrative surrounding the reception of his work, the left was under attack in ways of which Ellison was certainly keenly aware. But Ellison was also keenly aware of his audience and keenly aware of the representative stature that he and his work occupied during that period.

Invisible Man was a breakthrough novel that synthesized mid-twentiethcentury African American racial consciousness with America's broader cultural aspirations and accomplishments. It also became a place around which Ellison could subsequently orient his ideas about the obligations of the American writer: "The writer, any American writer, becomes basically responsible for the health of American literature the moment he starts writing seriously. And this regardless of his race or his religious background."2 But even as Ellison was being ushered into the intellectual conversation of race, politics, and art to which he had hoped his work would bring him, there were many who did not perceive Ellison to be particularly attuned to the African Americans about 
whom he wrote. Ellison's foundational ideas about the duties of black artists and intellectuals in the public sphere became a kind of a through-line in how he crafted and maintained his own public role in the age of civil rights.

Throughout the civil rights years, Ellison won numerous awards and was widely sought after to teach and lecture on college and university campuses. ${ }^{3}$ The novel itself regularly appeared on college reading lists across the country even though it received some harshly critical reviews, particularly from black and white critics on the left who felt that the novel disparaged and inaccurately depicted leftist ideology. Alternately, some middle-class black critics felt that the novel unnecessarily focused on representations of lower-class African Americans rather than emphasizing a view of black uplift that is represented by the presence of Booker T. Washington in the novel's vision of black progress, Emersonian self-reliance, and the narrator's own aspirational desire to become a leader and spokesman of his people. ${ }^{4}$ One thing that is quite clear, however, is that Ellison had no interest in pursuing an agenda-literary or political-of racial solidarity as a viable strategy for obtaining individual self-determination and humanity. Ellison himself spent that period occupying and defending a unique perspective in which he became recognized as (and criticized for) creating a critical counternarrative in which he positioned himself in the public consciousness as a black intellectual who purported to be less interested in propagating his blackness than he was in locating a black presence as a key component of America's history and national experience.

While scholars have examined Ralph Ellison from a variety of literary, cultural, and political perspectives that mine the components of his formative years for clues about his mature years, this article focuses on Ellison's conscious attempts after the publication of Invisible Man to recalibrate his audience's frame of reference to the elements that led to his artistic maturity. The dominant narrative surrounding Ellison most often focuses on Invisible Man and sees the novel as reflective of the process that led Ellison to leave the Tuskegee Institute after three years and relocate to Harlem, where he contributed to a number of leftist publications, wrote short fiction, and, after service in the U.S. Merchant Marine, began writing what became Invisible Man after having become radicalized by Richard Wright. The effects of that ideological transformation led to the composition and publication of a novel under whose shadow Ellison lived for the remainder of his life. While it suggests a natural, linear artistic and intellectual progression, that narrative is in many ways far too simple. In his biography of Ralph Ellison, Lawrence Jackson notes that Ellison's “career and his life hinged upon irony. Apparently untrained and untried, he had sent his first novel Invisible Man into the world and collected the National Book Awardthe 'bright hunk of gold,' as he called it — all in his thirty-ninth year."5 What Jackson's work describes most convincingly is that Ellison's work in composing Invisible Man reflected a genuine desire to articulate and address the "Negro Problem." Brown v. Board of Education and the civil rights movement eventually justified the ideas that Ellison had presented in his novel and gave him 
the opportunity to address those ideas in ways that put him in conflict with the political climate that developed in the 1950s and continued through the 1960s and early 1970s. In Wrestling with the Left, Barbara Foley has presented the most comprehensive examination available of the relation between Ellison's work with the Communist Party and his development as a novelist. Her finding is that Ellison's rejection of the left was different than the ideological origin story that he later put forth. One thing that her exhaustive research suggests is that Ellison's public stance in the years following Invisible Man was profoundly shaped by Ellison's own awareness of his position in a cultural setting that was rapidly changing around him. ${ }^{6}$

In Ralph Ellison in Progress, Adam Bradley reminds us of that rapidly changing landscape by noting that "the last half of Ellison's life coincided with seismic shifts in American politics and culture, from Jim Crow segregation to the civil rights revolution, from the death of the author to the birth of the digital age." ${ }^{7}$ While Bradley's focus is to read Ellison's unfinished second novel in relation to Invisible Man, his comment here highlights an important point about Ellison's public disposition when he notes the ways in which Ellison's work on his second novel during the civil rights era erases apparent reference to the contemporaneous political and social tumult. In his biography of Ellison, Arnold Rampersad notes a similar process of erasure at work in Invisible Man, which references the past (Reconstruction and World War I) but not the present (World War II) - at least not concretely. This is certainly part of the universalizing strategy that Barbara Foley recognizes Ellison undertaking at the expense of his earlier leftist involvement. ${ }^{8}$ This series of novelistic attempts to recast a broad, undefined present in the context of a narrowly defined past raises the question of how Ellison might have employed that same strategy in relation to his own public presence. As John S. Wright notes in Shadowing Ralph Ellison, "after the publication of Shadow and Act, a second phase of Ellison's passage into the heart of the American darkness balanced the continued growth of his literary reputation against the exactions of ideological warfare, with Ellison himself registering the consequent tensions in an increasingly embattled series of interviews in the late 1960s and early '70s."'

While those interviews, collected by Maryemma Graham and Amritjit Singh in Conversations with Ralph Ellison, certainly reflect some of the embattlement that Wright sees, they also reflect a divergence from the writer recognized by many, according to Graham and Singh, who "tend to think of Ellison as aloof in style and manner, the embodiment of his own metaphor, a kind of 'invisible man' of recent American literature. This may have been the public Ellison, a man overshadowed by his own reputation, chuckling with friends to deflect their questions about his second novel, and reluctant to claim most of what we have often wanted to attribute to him." 10

In the "Introduction to the Thirtieth-Anniversary Edition of Invisible Man," Ellison argued that the focus his fiction placed on human possibility (and the possibilities contained in social institutions) is reflective of the best and 
highest aspiration of politics: "While fiction is but a form of symbolic action, a mere game of 'as if,' therein lies its true function and its potential for effecting change. For at its most serious, just as is true of politics at its best, it is a thrust toward a human ideal." "11 For Ellison, the novel functions best when it functions in direct engagement with democracy rather than as a tool in the service of politicized ideology. ${ }^{12}$ Ellison was certainly not blind to the realities contained in the disparities between ideal and reality, principles and practice, aspiration and lived experience, or shadow and act. Invisible Man, his essays, interviews, public lectures, and even the unfinished second novel are all encircled by his understanding of the tensions framed by these very ideas. Although the perception of Ellison's political commitment has cast a broad shadow across so many of the ways Ellison is considered, if Ellison is read in conversation with the political thinkers and authors with whom he claimed to situate his work (and those against whom he situated his opposition), perhaps the most compelling critique of the actual political response that emerges is that Ellison was not able to provide clarity and insight about the nation's role - historically and in the nation's ever-emerging present-in defining and maintaining some kind of national ethos of American individualism.

Both Ellison's fiction and his nonfiction largely have their roots in the environment of an evolving black American consciousness of the effects of segregation, a consciousness that was ultimately bolstered by Brown v. Board of Education and the civil rights movement. The sense of possibility, ambiguously suggested at the conclusion of Invisible Man and presented more directly in his subsequent nonfiction work, is that American culture could not exist without a black presence. On the lower frequencies or elsewhere, race did not preclude the black artist or intellectual from speaking to (and on behalf of) all Americans. Although Invisible Man was written and published in the final years of legalized segregation in the United States, the novel was also profoundly forward looking in its ambiguous observations about the ways race is lived and experienced in a nation unable (or unwilling) to live up to the idealized aspirations contained in its founding documents.

The arrival of the end of legalized segregation did little to make either Ellison or the novel's pre-Brown v. Board of Education, pre-civil rights message seem dated or irrelevant. As a matter of fact, the rapid changes the nation underwent during the civil rights movement and the Black Arts, Black Power, and black nationalist years between 1955 and the mid-1970s actually burnished Ellison's reputation and the reputation of his novel. Although critics of all persuasions found Ellison's allusively modernist language unnecessarily distancing to all but a small segment of white readers and completely alienating to the black audience that it ostensibly depicted, the novel nevertheless came to epitomize a mid-twentieth-century sense of confessional alienation and disengagement. Invisible Man was chosen by a group of white critics polled by the New York Herald Tribune's Book Week in the September 26, 1965, issue as the best postWorld War II novel. The poll ranked Vladimir Nabokov's Lolita (1955) and J. 
D. Salinger's Catcher in the Rye (1954) just below it. Ellison himself placed near the top of the critics' poll ranking authors. ${ }^{13}$ Ellison's own counternarrative to the novel, in the form of interviews, essays, and even the publication of excerpts from his second novel, contributed to ceaseless scrutiny and reevaluation of Invisible Man.

The fact that the novel's focus is on the underground, the unseen, the overlooked, and the "lower frequencies" means that Ellison was able to present voices, circumstances, and political and social ideas that precede by decades, in some cases, the racial conflicts that were foregrounded after Brown v. Board of Education, the lynching of Emmett Till, the increasing effectiveness of the civil rights movement, the rise of the Black Power movement, and the New Breed writers associated with the Black Power movement. The novel also foreshadowed the rancorous discussions of canon and multiculturalism that consumed the 1980s and 1990s. The root of the idea to which Ellison returned over the course of his long writing career had its basis in his reading of nineteenthcentury American history. African Americans shaped the direction of American history through the culture, through resilient participation in mainstream America, and, perhaps most importantly, through an unwavering belief in the loftiest aspirations contained in America's democratic ideals. Ellison's work speaks relentlessly to this understanding of America's past. But for Ellison, the crucible that forged the experiences of black people living in America also forged the experiences of white Americans. Slavery and the failure of Reconstruction shaped the experience of life in America, not simply the experience of black life in America. Given Ellison's revisionary insistence on privileging literature's aesthetic dimensions over its political responsibilities, it is easy to understand the basis of many of the accusations of Ellison's apparent reluctance to engage politically with what was unfolding in the 1950s and 1960s. Ellison's views were in direct opposition to others of his generation whose work addressed the intersections of art, race, and politics. Richard Wright, for example, who had left the country in 1946, eventually to take up permanent residence in Paris, France, saw political engagement as literature's only response to global inequality. James Baldwin was similarly outspoken in his assessment of art and inequality, as was Amiri Baraka, who came from a position farther left and saw art as being inextricably linked to politics.

Yet Ellison was neither apolitical nor antipolitical. For Ellison, virtually all of his public work represented a kind of political action because so much of it contained the crucial element of social critique. To Ellison's way of thinking, his politicism differed in form and style, not commitment, from those who criticized him most harshly: "I never felt it necessary to go out and justify my militancy. My writings are there. I am not an ideologist. . . I'm not a separatist. The imagination is integrative. That's how you make the new-by putting something else with what you've got. And I'm unashamedly an American integrationist." 14 To put it as directly as possible, Ellison's view of his intellectual and artistic roles in the public sphere had virtually nothing to do with preserving and 
insisting on his blackness and virtually everything to do with making it clear to the American mainstream that black experience was synonymous with the nation's experience. All of Ellison's aesthetic work coalesced into an elaborate mosaic of social criticism that was itself a political act. While Ellison is sometimes seen as being politically distant, particularly relative to civil rights and Black Power activists, the counternarrative that Ellison constructed and maintained was that it was his art itself that defined a political stance rather than the other way around. The relationship between African Americans and the racialized political ideologies that involved black people relative to the nation were at the time most often being posited in particularly dualistic ways: integration and assimilation versus separatist nationalism. The question that Ellison raised in Invisible Man and quickly followed in his National Book Award acceptance speech in 1953, later published as "Brave Words for a Startling Occasion," has much more to do with how best to acknowledge the hybrid composition of the nation's past (and the contemporary lived experiences of its occupants) without simultaneously erasing and making invisible the very real differences of its citizens. ${ }^{15}$ How can the whole be understood as a place of integration for distinctly unique component parts? Ellison's view focused on the tension that existed between exerting one's individual rights and desires in the context of a larger democratic environment that impaired individual self-determination.

Ellison never stopped advocating for a position that recognized the shared, intertwined history of black and white Americans, which is not to say that Ellison saw the experience of that shared history to be the same for blacks as it was for whites. And Ellison never used his ideas about cultural hybridity as a point of departure for his own racial denial or as a justification for any kind of racial ambivalence whatsoever. His point of view as a racialized subject informed the way he conceptualized himself as an intellectual and literary artist in the public sphere. His ideas about cross-culturalism should not be taken to mean that racial difference did not exist for him. He had found segregation profoundly troubling. He found the discrimination spawned by the legacy of segregation to be deplorable. But perhaps the fact that Ellison's work compellingly identified the shortcomings of the nation's attitudes about race also meant that Ellison himself became identified with those shortcomings and, by extension, responsible for the formulation of solutions - or at least viable responses - to those shortcomings. ${ }^{16}$ While Ellison certainly recognized and accepted that responsibility, particularly as he obscured the radicalism that characterized the earlier years of his writing career in favor of emphasizing his aesthetic concerns, he emphatically resisted any pressure to formulate a response on the basis of ideology. Although he valued his racial membership, Ellison also realized that race alone put him in the position of being one voice among many: "I am, after all, only a minor member, not the whole damned tribe; in fact, most Negroes have never heard of me. I could shake the nation for a while with a crime or with indecent disclosures, but my pride lies in earning the right to call myself quite simply 'writer." 
Part of the cause for the formation of Ellison's intellectual and artistic opinions and the ways they were read may have as much to do with a combination of the nation's political changes as it did with the convergence of activist writing that shaped the spirit of the age. Ellison's literary authority continued to expand. His influence continued to deepen on the reputation of Invisible Man, the essays he published (and eventually collected in Shadow and Act, which he published in 1964), and the public's anticipation for his second novel, from which he had excerpted "And Hickman Arrives" in 1960, "Juneteenth" in 1965, and "Cadillac Flambé” in 1973. All told, Ellison published eight excerpted passages from the novel-in-progress between 1960 and 1977 and these pieces further fueled what was already keen anticipation for the follow-up to Invisible Man. But while Ellison continued to work, his writings and public lectures increasingly became seen as backward-looking, disengaged from the changes American society was rapidly undergoing, and overly integrationist in their focus on culture and literary craft. This view was reinforced by the publication of Shadow and Act, which was a backward-looking collection of essays that traced the impact of growing up in the former Oklahoma territories on Ellison's conception of race, nation, music, and literary art.

What is at stake in the disagreement between Ellison and the New Breed writers and activists with whom he found himself at odds is a reassessment of a series of fundamental assumptions about the nation's political, artistic, and social values. And the conflict was as much within black America as it was between the nation's mainstream and the often-competing beliefs operating within disparate strands of black social and political thought. The New Breed, at least as Larry Neal saw it in his afterword to Black Fire, could define itself only through its actions, and its actions could be rendered only through a synthesis of all the nationalistic movements that had preceded it. In doing so, New Breed writers recognized the need for an inherent separation between black writing and the nation that produced it: "Every black writer in America has had to react to this history, either to make peace with it, or make war with it. It cannot be ignored. Every black writer has chosen a particular stance towards it." 18 Black Arts writing saw itself as engaged in the elimination of double consciousness, not in the artistic integration of double consciousness. Ellison's writing and the narrative he continued to construct around it felt particularly irrelevant because the trope of invisibility that made Ellison's narrator invisible to both white and black people was antithetical to a movement that established itself on the premise that black people were not invisible to other black people. ${ }^{19}$ At a time when New Breed writers and activists were also interested in looking backward toward Jim Crow to justify their thoughts about a separate black nation, Ellison was using the legacy of segregation to argue against the viability of any cultural or artistic assessment that could not embrace the necessity of plurality and cultural integration.

Although Ellison contributed to leftist publications and attended Communist Party events like the League of American Writers Congress, which the 
party sponsored in 1937, Ellison subsequently claimed that he was less driven by what he labeled propagandistic dogma regarding the Negro struggle and instead claimed a far deeper concern with the influence and potential dissolution of black social, cultural, and political agency. In devising a narrative that dissented from fully embracing leftist thought, Ellison essentially, without embracing nationalist ideology, created an alternate nationalist vision predating the nationalism that subsequently rejected him. What Neal belatedly recognized in his 1970 essay titled "Ellison's Zoot Suit" was that Ellison's sleight of hand had substituted cultural inequality for Marxism's focus on class-based inequality. This is the idea that resurfaces in Ellison's disparaging response to Blues People: Negro Music in White America (1963), in which Amiri Baraka, who wrote at the time as LeRoi Jones, examines the cultural values conveyed through black music in America. ${ }^{20}$ Neal locates Ellison's earliest attempts to wrestle the often-competing (sometimes antithetical) claims of culture and politics in an unsigned editorial comment likely written by Ellison that appeared in the pages of The Negro Quarterly in 1943: "A third major problem, and one that is indispensible to the centralization and direction of power, is that of learning the meaning of the myths and symbols which abound among the Negro masses." ${ }^{21}$

At this early stage of his writing life, Ellison had already found himself stuck between two antithetical positions that remained in his writing consciousness in some form or other for the remainder of his life: how to articulate a meaningfully sustainable vision of identity and self-definition that is entirely distinct from the white cultural space in which it exists while simultaneously immersing itself in the chaos of competing impulses that define the American democratic process. ${ }^{22}$ In 1943, Ellison was trying to make these connections within the framework of Marxist ideology. Ellison's eventual decision was ostensibly to dismiss the political in favor of the artistic. For Ellison, politics discouraged the production of true art rather than stimulated it. Neal recognized what Ellison had begun working through a generation earlier and saw that the political confines imposed by a movement seemingly committed to black advancement in the 1960s and early 1970s could be as artistically confining as the leftist politics in which he participated during the years of his literary apprenticeship. Not everyone was as willing as Neal to reevaluate their thinking about Ellison's body of work relative to the New Breed writers and political activists working to leave behind Negroness in favor of blackness that increasingly recognized diasporic movements worldwide and brought these international coalitions into conversation with each other, sometimes under a broad, Marxist-inspired umbrella. The ideas at the heart of Invisible Man are that an antihero is unable to come to terms with the various visible and invisible political agendas competing for his acceptance. The black left grappled with these ideas in the 1930s and 1940s. These same ideas were also recognized by $1960 \mathrm{~s}$ black radical writers and activists. While Ellison was reluctant to draw a direct line of connection between his experiences with the left and 1960s black radical 
writing, the narrative he devised functioned around the dangers of subordinating art to politics. For Ellison, folklore, not political ideology, reached to the most profound areas of the black presence in the United States: "In folklore we tell what Negro experience really is."${ }^{.23}$ That is the element evident in the unsigned Negro Quarterly comment that I earlier cited, toward which Ellison was reaching even during the Marxist phase of his writing life.

If there is a recurring political theme in Ellison's recalibration of his audience's response to his ideas between the publication of Invisible Man and the conclusion of the civil rights years, it could certainly be the risks involved in the politics of introspection. Leaving aside Ellison's thoughts about the Rev. Dr. Martin Luther King, Jr., the civil rights movement, and his unwavering support for President Lyndon B. Johnson, Ellison's insistence on the centrality of black people in the United States as American was crucial to understanding any larger conception of the nation. This view meant that his ideas about what amounts to pluralistic hybridity were more than at odds with a movement that valued something they termed black authenticity and, increasingly for some, black separatism.

In a letter that Ellison wrote to his friend Stanley Edgar Hyman on May 29, 1970 (it was later published in New Republic in the March 1, 1999, issue of the magazine under the title "American Culture Is of a Whole"), Ellison angrily wrote, "As you damn well know, I view my people as American and not African, and while our experience differs in unique ways from that of white Americans, it is never absolutely at variance with the dominant American mode. Diversity within unity is the confounding reality." ${ }^{24}$ Ellison's unwavering insistence on cross-culturalism was the piece that, for many, bound Ellison more closely to the problem rather than to its solution. His insistence on ignoring the urgencies of civil rights and the nation's increasing military involvement in Southeast Asia in favor of lectures focused on nineteenth-century literature certainly did not help bolster his public stature as a black artist and intellectual for many of the next generation's black intellectuals and artists. Ellison's apparent disdain for much of the nation's black leadership seems to suggest his belief in the impossibility of a viable public role for black artists and intellectuals who waded out of the realm of art and intellectualism and into the world of activism. As Invisible Man continued to take on a life of its own while Ellison struggled with the decades-long composition of his second novel, he saw the world he was attempting to chronicle as being a mass of fluidity. He had recognized and championed that view of fluidity earlier as a kind of American exceptionalism but now argued that pluralistic fluidity had become the very glue that cemented black experience to America's democratic experience.

With that sense of fluidity in mind, perhaps it is in "The Completion of Personality" where what Ellison says about his writing also seems to speak most forcefully toward art and his extraordinarily self-contained presence as a public intellectual: "You just write for your own time, while trying to write in terms of the density of experience, knowing perfectly well that life repeats itself. Even 
in this rapidly changing United States it repeats itself. The mystery is that while repeating itself it always manages slightly to change its mask. To be able to grasp a little of that change within continuity, to communicate it across all these divisions of background and individual experience, seems enough for me. If you're lucky, of course, if you splice into one of the deeper currents of life, then you have a chance of your work lasting a little longer." 25

\section{Notes}

1. Lawrence Jackson, Ralph Ellison Emergence of Genius (New York: John Wiley and Sons, 2002), ix. The novel reached number eight on the New York Times best-seller list but had a profound influence on American literature, on the national conversation about race and its social and political implications, and on the subsequent trajectory of Ellison's intellectual and artistic work for the remainder of his life.

2. Maryemma Graham and Amritjit Singh, eds., Conversations with Ralph Ellison (Jackson, MS: University Press of Mississippi, 1995), 122. Also quoted in Lawrence Buell, The Dream of the Great American Novel (Cambridge, MA: Belknap Press of Harvard University Press, 2014), 176.

3. During the civil rights years, Ellison was sought after to teach at Bard College; Columbia University; Princeton University; the University of Chicago; the University of California, Los Angeles; Yale University; Rutgers University; and New York University. He served, between 1961 and 1969, on the Legal Defense Committee of 100 of the National Association for the Advancement of Colored People, which approved legal defense fund-raising for the association's nonviolent sit-ins and Freedom Rides throughout the South. His work was recognized for acknowledgment by the American Academy of Arts and Letters in Rome, he became a member of the National Council on the Arts (which was later reorganized into the National Endowment for the Arts and the National Endowment for the Humanities), he served for nine years on the Carnegie Commission on Educational Television, he received the Presidential Medal of Freedom from President Lyndon B. Johnson in 1969, he received the Chevalier de l'Ordre des Artes et Lettres from France's Ministry of Cultural Affairs, he became a member of the Century Club (an exclusive previously all-white male social club), and he was elected in 1975 to the American Academy of Arts and Letters.

4. For summaries of reviews of Invisible Man, see Jackson, Emergence of Genius, and Arnold Rampersad, Ralph Ellison: A Biography (New York: Alfred A. Knopf, 2007).

5. Jackson, Emergence of Genius, ix.

6. Barbara Foley, Wrestling with the Left: The Making of Ralph Ellison's Invisible Man (Durham, NC: Duke University Press, 2010).

7. Adam Bradley, Ralph Ellison in Progress: From Invisible Man to Three Days before the Shooting ... (New Haven, CT: Yale University Press, 2010), 9.

8. Foley argues very persuasively that Ellison added the epilogue in an attempt to make white readers feel more comfortable. This is certainly the area of the novel that invokes the specter of universalism most forcefully, particularly in the narrator's closing invitation to unite an otherwise fractious, disparate readership. Foley, Wrestling, 325-29, 336-49.

9. John S. Wright, Shadowing Ralph Ellison (Jackson: University Press of Mississippi, 2006),

10. Graham and Singh, Conversations, xi.

11. Ralph Ellison, "Introduction to the Thirtieth-Anniversary Edition of Invisible Man." In The Collected Essays of Ralph Ellison, edited by John F. Callahan (New York: Modern Library, 1995), 482. $755-57$.

12. Ralph Ellison, "The Novel as a Function of Democracy." In Callahan, ed., Collected Essays,

13. Buell, The Dream, 180-81.

14. Graham and Singh, Conversations, 235. See also Timothy Parrish, Ralph Ellison and the Genius of America (Amherst: University of Massachusetts Press, 2012), 131 n. 1; Ross Posnock, Color and Culture: Black Writers and the Making of the Modern Intellectual (Cambridge, MA: Harvard University Press, 1998), 9; and Danielle S. Allen, Talking to Strangers: Anxieties of Citizenship since Brown v. Board of Education (Chicago: University of Chicago Press, 2004), 27.

15. This is precisely the point made by Allen, Talking to Strangers, 18-19, 27-31. See also Parrish, Genius of America, 128-40.

16. Ralph Ellison, "The World and the Jug." In Callahan, ed., Collected Essays, 171-85.

17. Ellison, "The World and the Jug," In Callahan, ed., Collected Essays, 185.

18. LeRoi Jones and Larry Neal, eds. Black Fire: An Anthology of Afro-American Writing (New York: Morrow, 1968), 647.

19. Jones and Neal, Black Fire, 652. 


\section{Sterling Lecater Bland Jr.}

20. Larry Neal, “Ellison's Zoot Suit,” in Speaking for You: The Vision of Ralph Ellison, edited by Kimberly W. Benston (Washington, DC: Howard University Press, 1987), 111-13.

21. Ralph Ellison, "Editorial Comment," Negro Quarterly: A Review of Negro Life and Culture 1, no. 4 (Winter/Spring 1943): 301. Ellison served as the journal's managing editor. Given the editorial's subject matter, its approach to the theme, its tone, and the development of its ideas, it is entirely reasonable to ascribe authorship to Ellison. Angelo Herndon is listed on the masthead as editor in chief, but Ellison, who was far less well known in leftist circles, is recognized to have borne the greater responsibility in obtaining contributions to the journal.

22. Neal, "Ellison's Zoot Suit," 112.

23. Ralph Ellison, "A Very Stern Discipline." In Callahan, ed., Collected Essays, 733.

24. Ralph Ellison, Letter to Stanley Edgar Hyman dated May 29, 1970, in "American Culture Is of a Whole: From the Letters of Ralph Ellison," with an introduction by John F. Callahan, New Republic 220, no. 9 (March 1, 1999), 41

25. Ralph Ellison, “A Completion of Personality.” In The Collected Essays of Ralph Ellison, edited by John F. Callahan (New York: Modern Library, 1995), 806. 